\title{
Ethnic-Related Characteristics of Lipid and Carbohydrate Metabolism in the Indigenous Population of Yakutia
}

\author{
Sargylana I. Sofronova, PhD*; Maria P. Kirillina, PhD; Vyacheslav M. Nikolaev, PhD; \\ Anna N. Romanova, MD; Matrena N. Mikhailova; Irina V. Kononova, PhD \\ Yakut Science Center of Complex Medical Problems \\ Yakutsk, the Republic of Sakha (Yakutia), Russia
}

\begin{abstract}
Background: The objective of our research was to study the ethnic-related characteristics of lipid and carbohydrate metabolism in the indigenous population of Yakutia.

Methods and Results: The study was conducted under expeditionary conditions in the North of Yakutia (Nizhnekolymsky, Anabarsky, Verkhnekolymsky, Tomponsky, and Srednekolymsky districts). In total, 529 people aged between 20 and 70 years were examined in the primary health care units. For a comparative analysis, we formed 6 ethnic groups (Yakuts, Evenks, Evens, Dolgans, Chukchi, Yukagirs). In all ethnic groups, there was a high prevalence of atherogenic dyslipidemia, with the highest frequency in Evenks and Yakuts. Women had a higher frequency of lipid metabolism disorders than men did. The frequency of hyperglycemia was significantly higher among the Dolgans, Evenks and Yakuts than in other ethnic groups.

Conclusion: This study showed a high frequency of metabolic syndrome in the examined ethnic groups, which is caused by a change in the traditional lifestyle and the nature of nutrition. (International Journal of Biomedicine. 2020;10(1):58-60.)
\end{abstract}

Key Words: hypercholesterolemia $\bullet$ hyperglycemia $\bullet$ indigenous population $\bullet$ Yakutia

\section{Abbreviations}

BMI, body mass index; CE, cholesterolemia; FPG, fasting plasma glucose; HTG, hypertriglyceridemia; HCE, hypercholesterolemia; HG, hyperglycemia; HDL-C, high-density lipoprotein cholesterol; IGT, impaired glucose tolerance; LDL-C, low-density lipoprotein cholesterol; PG, postload glucose; TC, total cholesterol; TG, triglycerides; MetS, metabolic syndrome

\section{Introduction}

Cardiovascular disease (CVD) is one of the leading causes of mortality in Yakutia, as it is across Russia. According to the Federal State Statistics Service, the CVD morbidity rate of the population remained on the same level from 2013 to 2015 , and the mortality decreased slightly by $0.9 \%$, making the mortality rate $45.4 \%{ }^{(1)}$

The association between metabolic syndrome (MetS) and the total mortality from cardiovascular diseases is becoming more and more evident. ${ }^{(2-6)} \mathrm{An}$ important point in the study of

*Corresponding author: Sargylana I. Sofronova, PhD. Yakut Science Center of Complex Medical Problems. Yakutsk, the Republic of Sakha (Yakutia), Russia.E-mail: sara2208@mail.ru
MetS is the identification of its characteristics in different ethnic groups with the peculiarities of culture and lifestyle. (7)

The objective of our research was to study the ethnicrelated characteristics of lipid and carbohydrate metabolism in the indigenous population of Yakutia.

\section{Materials and Methods}

The study was conducted under expeditionary conditions in the North of Yakutia (Nizhnekolymsky, Anabarsky, Verkhnekolymsky, Tomponsky, and Srednekolymsky districts). In total, 893 people aged between 20 and 70 years were examined in the primary health care units. The sample was formed according to the lists of employees located in the administrations of the villages. The response was $76 \%$. 
The present study included 529 indigenous people of Yakutia. For a comparative analysis, we formed 6 ethnic groups (Yakuts, Evenks, Evens, Dolgans, Chukchi, Yukagirs) (Table 1). The average age of respondents was $45.59 \pm 0.55$ years.

\section{Table 1.}

Ethnic characteristics of the indigenous population of Yakutia

\begin{tabular}{|l|c|c|c|c|c|c|}
\hline & $\begin{array}{c}\text { Yakuts } \\
(\mathrm{n}=119)\end{array}$ & $\begin{array}{c}\text { Dolgans } \\
(\mathrm{n}=85)\end{array}$ & $\begin{array}{c}\text { Evens } \\
(\mathrm{n}=141)\end{array}$ & $\begin{array}{c}\text { Evenks } \\
(\mathrm{n}=67)\end{array}$ & $\begin{array}{c}\text { Chukchi } \\
(\mathrm{n}=40)\end{array}$ & $\begin{array}{c}\text { Yukagirs } \\
(\mathrm{n}=77)\end{array}$ \\
\hline Men, n/\% & $30 / 25.2$ & $26 / 30.6$ & $51 / 36.2$ & $13 / 19.4$ & $20 / 50$ & $34 / 44.2$ \\
\hline Women, n/\% & $89 / 74.8$ & $59 / 69.4$ & $90 / 63.8$ & $54 / 80.6$ & $20 / 50$ & $43 / 55.8$ \\
\hline $\begin{array}{l}\text { Average age, } \\
\text { yrs }\end{array}$ & $\begin{array}{c}48.94 \pm \\
1.0\end{array}$ & $\begin{array}{c}44.93 \pm \\
1.56\end{array}$ & $\begin{array}{c}43.02 \pm \\
0.98\end{array}$ & $\begin{array}{c}48.37 \pm \\
1.64\end{array}$ & $\begin{array}{c}39.73 \pm \\
1.93\end{array}$ & $\begin{array}{c}46.49 \pm \\
1.54\end{array}$ \\
\hline
\end{tabular}

The research program included the following sections: 1) The collection of anamnestic data, physical examination, and anthropometric data analysis [BMI $\left.\left.\left(\mathrm{kg} / \mathrm{cm}^{2}\right)\right] ; 2\right)$ Assessment of FPG, OGTT, and blood levels of TG, HDL-C, LDL-C.

Glucose and lipid metabolism disorders were diagnosed according to the Russian national recommendations (the AllRussian Scientific Society of Cardiologists [VNOK, 2012] $)^{(2)}$ based on the European recommendations $(2011)^{(3)}$ : TC $\geq 5.0$ $\mathrm{mmol} / \mathrm{l}$; LDL-C $>3.0 \mathrm{mmol} / \mathrm{l}$; HDL-C $<1.0 \mathrm{mmol} / \mathrm{l}$ in males and $<1.2 \mathrm{mmol} / 1$ in females; $\mathrm{TG} \geq 1.7 \mathrm{mmol} / \mathrm{l} ; \mathrm{FPG}>6.1$ $\mathrm{mmol} / \mathrm{l} ;$ IGT $2 \mathrm{Hr}$ PG $\geq 7.8 \mathrm{mmol} / \mathrm{l}$ and $\leq 11 \mathrm{mmol} / \mathrm{l}$.

Blood was taken from the ulnar vein in accordance with the existing requirements in the morning after an overnight fast. After blood centrifugation, the serum was stored at $-70^{\circ} \mathrm{C}$ until analysis. The serum lipid spectrum was determined by enzymatic method on a Labio 200 automatic biochemical analyzer using Analyticon reagents (Germany).

The study was approved by the Ethics Committee of the Yakut Science Center of Complex Medical Problems. Written informed consent was obtained from each patient.

Statistical analysis was performed using SPSS (version 19.0). Baseline characteristics were summarized as frequencies and percentages for categorical variables and as mean \pm SEM for continuous variables. Means of 2 continuous normally distributed variables were compared by independent samples
Student's t test. Mann-Whitney U test was used to compare means of 2 groups of variables not normally distributed. The frequencies of categorical variables were compared using the Chi-square test. A probability value of $P<0.05$ was considered statistically significant.

\section{Results and Discussion}

An ethnicity-dependent comparative characteristic of the average values of the lipid profile and blood glucose is presented in Table 2. Data obtained showed that the average values of TC exceeded the normal range in Yakuts and Evenks, compared with other ethnic groups. Women had higher values of TC than men did. The level of LDL-C was higher than the reference values in all the studied representatives of the indigenous population, both in men and women. For other indicators, the average concentration of blood parameters did not exceed the normal range.

The average frequency of HCE, HTG, hyper-LDL-CE, hypo-HDL-CE, and carbohydrate spectrum disorders depending on ethnicity is presented in Figure 1. The frequency of $\mathrm{HCE}$ was high in all ethnic representatives. The HCE frequency was significantly higher in the Yakuts (58.8\%) than in the Yukagirs $(P<0.001)$, Evens $(P<0.004)$, and Dolgans $(P=0.01)$. The lowest frequency of HCE was observed in the Yukagirs (37.7\%). These data are consistent with literature data. The prevalence of HCE in Russia, according to ESSE epidemiological studies, was $62 \%{ }^{(8,9)}$

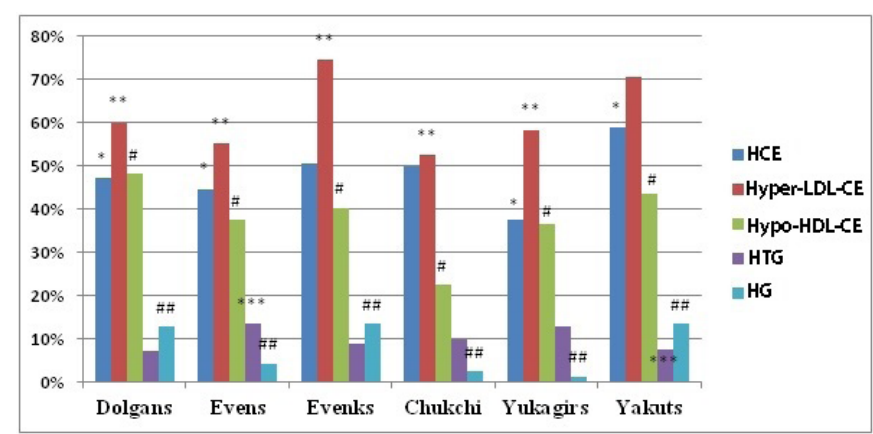

Fig.1. The frequency of dyslipidemia and hyperglycemia depending on ethnicity

* $-P<0.05$ for HCE; ** $-P<0.05$ for Hyper-LDL-CE; \# - $P<0.05$ for Hypo-HDL-CE; *** - $P<0.05$ for $H T G$; \#\# - $P<0.05$ for $H G$

Table 2.

The average values of the lipid profile and blood glucose in the indigenous population of Yakutia

\begin{tabular}{|c|c|c|c|c|c|c|c|c|c|c|c|c|c|c|c|c|c|c|}
\hline \multirow{2}{*}{ Variable } & \multicolumn{3}{|c|}{ Yakuts } & \multicolumn{3}{|c|}{ Evenks } & \multicolumn{3}{|c|}{ Evens } & \multicolumn{3}{|c|}{ Dolgans } & \multicolumn{3}{|c|}{ Chukchi } & \multicolumn{3}{|c|}{ Yukagirs } \\
\hline & total & men & men & total & men & en & tal & men & wor & total & nen & $\mathrm{n}$ & tal & men & women & tal & men & women \\
\hline & 0.10 & $\begin{array}{c}4.93 \pm \\
0.25\end{array}$ & 0 & $\begin{array}{c}5.41 \pm \\
0.24\end{array}$ & $\begin{array}{c}5.66 \pm \\
0.61\end{array}$ & 0 & $\begin{array}{c}4.76 \pm \\
0.07\end{array}$ & $\begin{array}{l} \pm \\
8\end{array}$ & & $\begin{array}{c}5.17 \pm \\
0.09\end{array}$ & $\begin{array}{c}5.38 \pm \\
0.12\end{array}$ & & & $\begin{array}{c}4.44 \pm \\
0.31\end{array}$ & & $\begin{array}{c}3.82 \pm \\
0.12\end{array}$ & $=\begin{array}{c}3.81 \pm \\
0.22\end{array}$ & \\
\hline $\begin{array}{l}\mathrm{TG}, \\
\mathrm{mmol} / \mathrm{l}\end{array}$ & $\begin{array}{c}1.03 \pm \\
0.04\end{array}$ & $\begin{array}{c}1.01 \pm \\
0.06\end{array}$ & $\begin{array}{c}1.03 \pm \\
0.05\end{array}$ & $\begin{array}{c}1.02 \pm \\
0.06\end{array}$ & $\begin{array}{c}1.02 \pm \\
0.14\end{array}$ & $\begin{array}{c}1.03 \pm \\
0.07\end{array}$ & $\begin{array}{c}1.12 \pm \\
0.04\end{array}$ & $\begin{array}{c}1.18 \pm \\
0.08\end{array}$ & $\begin{array}{c}1.08 \pm \\
0.05\end{array}$ & $\begin{array}{c}0.84 \pm \\
0.05\end{array}$ & $\begin{array}{c}0.76 \pm \\
0.08\end{array}$ & & $\begin{array}{c}0.98 \pm \\
0.08\end{array}$ & $\begin{array}{c}1.04 \pm \\
0.11\end{array}$ & & $\begin{array}{c}1.09 \pm \\
0.06\end{array}$ & $\begin{array}{c}1.13 \pm \\
0.09\end{array}$ & 0.08 \\
\hline $\begin{array}{l}\mathrm{TC}, \\
\mathrm{mmol} / \mathrm{l}\end{array}$ & $\begin{array}{c}5.18 \pm \\
0.08 \\
\end{array}$ & $\begin{array}{c}4.96 \pm \\
0.16 \\
\end{array}$ & $\begin{array}{c}5.26 \pm \\
0.09 \\
\end{array}$ & $\begin{array}{c}5.17 \pm \\
0.10 \\
\end{array}$ & $\begin{array}{c}5.15 \pm \\
0.15 \\
\end{array}$ & $\begin{array}{c}5.18 \pm \\
0.12 \\
\end{array}$ & $\begin{array}{c}4.93 \pm \\
0.08 \\
\end{array}$ & $\begin{array}{c}5.04 \pm \\
0.14 \\
\end{array}$ & $\begin{array}{c}4.86 \pm \\
0.09 \\
\end{array}$ & $\begin{array}{c}4.86 \pm \\
0.10 \\
\end{array}$ & \begin{tabular}{|c|}
$4.77 \pm$ \\
0.21 \\
\end{tabular} & $\begin{array}{c}4.90 \pm \\
0.11 \\
\end{array}$ & $\begin{array}{c}4.96 \pm \\
0.15 \\
\end{array}$ & $\begin{array}{c}4.94 \pm \\
0.26\end{array}$ & $\begin{array}{c}4.98 \pm \\
0.14 \\
\end{array}$ & $\begin{array}{c}4.89 \pm \\
0.10 \\
\end{array}$ & $\begin{array}{c}4.78 \pm \\
0.15\end{array}$ & $\begin{array}{c}4.98 \pm \\
0.15 \\
\end{array}$ \\
\hline $\begin{array}{l}\mathrm{HDL}, \\
\mathrm{mmol} / 1\end{array}$ & $\begin{array}{c}1.23 \pm \\
0.02 \\
\end{array}$ & $\begin{array}{c}1.11 \pm \\
0.05\end{array}$ & $\begin{array}{c}1.27 \pm \\
0.03\end{array}$ & $\begin{array}{c}1.27 \pm \\
0.06\end{array}$ & $\begin{array}{c}1.10 \pm \\
0.09\end{array}$ & $\begin{array}{c}1.31 \pm \\
0.07\end{array}$ & $\begin{array}{l}1.25 \pm \\
0.02\end{array}$ & $\begin{array}{c}1.25 \pm \\
0.05\end{array}$ & $\begin{array}{c}1.25 \pm \\
0.03\end{array}$ & $\begin{array}{c}1.20 \pm \\
0.04\end{array}$ & $\begin{array}{c}1.16 \pm \\
0.08\end{array}$ & $\begin{array}{c}1.22 \pm \\
0.04\end{array}$ & $\begin{array}{c}1.42 \pm \\
0.07 \\
\end{array}$ & $\begin{array}{c}1.37 \pm \\
0.11\end{array}$ & $\begin{array}{c}1.48 \pm \\
0.09\end{array}$ & $\begin{array}{c}1.22 \pm \\
0.03\end{array}$ & $\begin{array}{c}1.20 \pm \\
0.66\end{array}$ & $\begin{array}{c}1.23 \pm \\
0.03\end{array}$ \\
\hline $\begin{array}{l}\mathrm{LDL}, \\
\mathrm{mmol} / 1\end{array}$ & $\begin{array}{c}3.47 \pm \\
0.07\end{array}$ & $\begin{array}{c}3.36 \pm \\
0.15\end{array}$ & $\begin{array}{c}3.51 \pm \\
0.08\end{array}$ & $\begin{array}{c}3.49 \pm \\
0.08\end{array}$ & $\begin{array}{c}3.57 \pm \\
0.11\end{array}$ & $\begin{array}{c}3.47 \pm \\
0.10\end{array}$ & $\begin{array}{c}3.16 \pm \\
0.07\end{array}$ & $\begin{array}{c}3.27 \pm \\
0.13\end{array}$ & $\begin{array}{c}3.11 \pm \\
0.08\end{array}$ & $\begin{array}{c}3.26 \pm \\
0.08\end{array}$ & $\begin{array}{c}3.27 \pm \\
0.16\end{array}$ & $\begin{array}{c}3.26 \pm \\
0.10\end{array}$ & $\begin{array}{c}3.08 \pm \\
0.12\end{array}$ & $\begin{array}{c}3.09 \pm \\
0.20\end{array}$ & $\begin{array}{c}3.06 \pm \\
0.12\end{array}$ & $\begin{array}{c}3.15 \pm \\
0.08\end{array}$ & $\begin{array}{c}3.07 \pm \\
0.12\end{array}$ & $\begin{array}{c}3.21 \pm \\
0.12\end{array}$ \\
\hline
\end{tabular}


The frequency of hyper-LDL-CE was high in all members of the indigenous nationality (more than half), with the highest rate (74.6\%) among the Evenks and Yakuts (70.6\%). Statistically significant differences were noted between the Evenks and the Chukchi $(P<0.001)$, Evens $(P<0.001)$, Yukagirs $(P=0.003)$, and Dolgans $(P=0.007)$. We found a high direct correlation ( $\mathrm{r}=0.929$, $P<0.000$ ) between the levels of TC and LDL-C.

The frequency of hypo-HDL-CE was significantly higher among the Dolgans (48.5\%), Evens (37.6\%), Evenks (40.3\%), Yukagirs (36.4\%), and Yakuts (43.7\%) than it was among the Chukchi (22.5\%). Frequency of HTG varied in the range from $7.1 \%$ in Dolgans to $13.5 \%$ in Evens. Statistically significant differences were noted between Yakuts and Evens $(P=0.02)$.

The frequency of HG was significantly higher among Dolgans (12.9\%), Evenks and Yakuts (13.4\%) than in Evens (4.3\%), Chukchi (2.5\%), and Yukagirs (1.3\%).

When comparing the frequency of lipid and carbohydrate metabolism disorders on a gender basis, the data obtained were comparable to the data on ethnic groups in general. It should be noted that Yakut and Dolgan women had a greater frequency of HCE than men did. Hypo-HDL-CE prevailed among women, compared to men, in all ethnic groups except for the Chukchi. The frequency of HG was highest among Dolgan men and Yakut women.

Thus, in all ethnic groups, there was a high prevalence of atherogenic dyslipidemia, with the highest frequency in Evenks and Yakuts. Women had a higher frequency of lipid metabolism disorders than men did. The frequency of hyperglycemia was significantly higher among the Dolgans, Evenks and Yakuts than in other ethnic groups. Our study showed a high frequency of MetS in the examined ethnic groups, which is caused by a change in the traditional lifestyle and the nature of nutrition. The high frequency of atherogenic dyslipidemia in representatives of various ethnic groups of the indigenous population of Yakutia is of scientific-clinical interest. In the public health arena, the results of this study are important for the development of regional policies to preserve the basic traditional principles of lifestyle and nutrition for the indigenous population in order to optimize preventive measures for cardiovascular diseases.

\section{Competing Interests}

The authors declare that they have no competing interests.

\section{References}

1. Health care in the Republic of Sakha (Yakutia): Statistical collection / Sakha (Yakutia) stat. Yakutsk, 2016. [In Russian]. 2. Aronov DM, Arabidze GG, Akhmedzhanov NM, Balakhonova TV, Boytsov SA, Bubnova MG , et al. Russian recommendations. Revision V. Russian Cardiology Journal. 2012;5(97):1-32. [In Russian].

3. European Association for Cardiovascular Prevention \& Rehabilitation, Reiner Z, Catapano AL, De Backer G, Graham I, Taskinen MR, Wiklund O, et al.; ESC Committee for Practice Guidelines (CPG) 2008-2010 and 2010-2012 Committees. ESC/EAS Guidelines for the management of dyslipidaemias: the Task Force for the management of dyslipidaemias of the European Society of Cardiology (ESC) and the European Atherosclerosis Society (EAS). Eur Heart J. 2011 Jul;32(14):1769-818. doi: 10.1093/eurheartj/ehr158.

4. Lorenzo C, Williams K, J. Hunt K, M. Haffner S. The National Cholesterol Education Program - Adult Treatment Panel III, International Diabetes Federation, and World Health Organization Definitions of the Metabolic Syndrome as Predictors of Incident Cardiovascular Disease and Diabetes. Diabetes Care. 2007;30(1):8-13.

5. Ford ES. Risks for all-cause mortality, cardiovascular disease, and diabetes associated with the metabolic syndrome: a summary of the evidence. Diabetes Care. 2005;28(7):176978.

6. Gami AS, Witt BJ, Howard DE, Erwin PJ, Gami LA, Somers VK, Montori VM. Metabolic syndrome and risk of incident cardiovascular events and death: a systematic review and meta-analysis of longitudinal studies. J Am Coll Cardiol. 2007;49(4):403-14.

7. Mamedov MN, Oganov RG. [Epidemiological aspects of the metabolic syndrome]. Kardiologiia. 2004; 44(9):4-8. [Article in Russian].

8. Muromtseva GA, Kontsevaya AV, Konstantinov VV, Artamonova GV, Gatagonova TM, Duplyakov DV, et al. [The prevalence of non-infectious diseases risk factors in Russian population in 2012-2013 years. The results of ECVD-RF]. Cardiovascular Therapy and Prevention. 2014;13(6):4-11. [Article in Russian].

9. Scientific and organizational committee of the project ESSE-RF. Epidemiology of cardiovascular diseases in different regions of Russia (ESSE-RF). The rationale for and design of the study. Russian Journal of Preventive Medicine and Public Health. 2013;16(6):25-34. [Article in Russian]. 